\title{
Estrogen and Susceptibility of Alzheimer's Disease
}

\author{
Shengjiao Wei, Wei Zhang and Jingshan Shi* \\ Key Laboratory of Basic Pharmacology of Ministry of Education and Joint International Research Laboratory of Ethnomedicine of Ministry of \\ Education, Zunyi Medical University, China
}

Submission: December 11, 2019; Published: December 16, 2019

*Corresponding author: Jingshan Shi, Key Laboratory of Basic Pharmacology of Ministry of Education and Joint International Research Laboratory of Ethnomedicine of Ministry of Education, Zunyi Medical University, Zunyi Guizhou, China

Abstract

Estrogen is of great importance in regulating normal reproductive and non-reproductive functions. Aromatase is a key enzyme for the biosynthesis of estrogen in the body. The physiological roles of estrogen is mediated by estrogen receptors (ERs). When estrogen levels and/or the expression of its receptor protein are disrupted in the body, it can lead to diseases such as osteoporosis, and may increase susceptibility to diseases such as alzheimer's disease (AD). This paper reviews the relationship between estrogen and AD susceptibility.

Keywords: Estrogen; Aromatase; Estrogen receptors; Alzheimer's disease

Abbrevations: AD: Alzheimer’s Disease; A $\beta$ : Abeta Amyloid Protein; ERs: Estrogen Receptors; LTCC: L-type Ca2+ Channels

\section{Introduction}

Alzheimer's disease (AD) is the most common form of dementia, accounting for $50-60 \%$, and is a typical progressive neurodegenerative disease $[1,2]$. AD is characterized by a number of pathological features, notably extracellular senile plaques formed by the aggregation of Abeta amyloid protein $(A \beta)$ and the neurofibrillary tangles (NFTs) in the neuronal cells formed by hyperphosphorylation Tau protein, accompanied by important pathological changes such as brain neuron death, synaptic loss and reactive gliosis [3]. The clinical manifestations of AD are differ at different disease stages. Clinically, AD is a progressive disorder characterized by loss of early memory discontinuity and decline in overall cognitive function in late advanced stages and by behavioral symptoms such as aphasia, misuse, depression, and anxiety; memory impairment and crystallized abilities are remained $[4,5]$. In recent years, epidemiological retrospective studies have shown that sex steroids are inversely associated with risk of $\mathrm{AD}$, and estradiol seem to play neuroprotective role in AD. Endogenous estrogens is the most common in women after menopause [6]. Epidemiologic studies have reported that postmenopausal females have increase susceptibility of $\mathrm{AD}$ when compared with age-matched males. Studies have also shown that women endogenous estrogen have decreased in early menopause in women, and it is closely related to the incidence of $\mathrm{AD}[7,8]$.

\section{Endogenous Estrogen Synthesis}

Aromatase is one of cytochrome P450 enzyme systems, which can catalyze androstenedione and testosterone to convert irreversibly to estradiol and estrone, respectively. It is the rate-limiting enzyme for estrogen biosynthesis and is located in the endoplasmic reticulum of estrogen-producing cells [9]. Aromatization of androgen and production of estrogen molecule by aromatase has a double action. However, androgens may have no significant change in concentration by removing androgen molecules, estrogens are mole for mole over 100 times more active than androgens [10]. Studies have shown that there are gender differences in the expression and activity of aromatase, and it is higher aromatization expression in males than females and convert androgens to estrogens to induce masculine sexual behavior [11-13]. Most of early studies were limited to the role of aromatase in the regulation of estrogen in animals. In recent years, there has been a new explanation for aromatase, that is, aromatase plays a role in the regulation of female behavioral end points and physiological [14]. Some studies have shown that the role of aromatase is not only involved in the synthesis of estrogen, but also involved in functional regulation. Early work had shown that aromatase plays an important role in the treatment of neurodegenerative diseases and cancer $[15,16]$. These studies suggested that aromatase promotes local estrogen production, 
which regulates brain function. In addition, aromatase can promote sufficient levels of estrogen in the brain when it exerts antioxidant effects to promote neuroprotective effects [15].

\section{Physiological Function of Estrogen}

Estrogen can promote the development of secondary sexual characteristics and sexual organ maturation in female animals. Other broad physiological regulatory roles include bone mature, organic components [17], cardiovascular system, central nervous system and metabolism [18-20]. The main source tissues of estrogenare ovary and placenta in female animals, and granulosa cells are crucialto produce estrogen. It includes three chemically different types in body: estradiol, estrone, and estriol, in which estradiol is the predominant exist [21-25]. The classical active mode of estrogen is through the activation of the receptors [26], by which estradiolas ligand-dependent transcription factors regulate the expression of target genes in the nucleus [27]. Estrogens act through two major categories of estrogen receptors (ERs): the classical nuclear receptor including ER1 and ER2, and another membranous receptors including membranous components of classical nuclear receptors and GPER1 (GPR30) and ER$\mathrm{X}$. ERs signaling pathway can also be mediated via the activation of some protein kinase cascades, such as MAPK/ERK, PI3K/AKT [28], by which cognitive behaviors is regulated.

\section{Estrogen Receptors}

Estrogen plays an important role in the repair of more than one disease, including angiocardiopathy $[18,29]$, osteoporosis [30], spondyloarthritis [31], brest cancer [32], AD and Parkinson disease $[33,34]$. Recent studies have shown that estradiol replacement therapy in obese model of male mice induced by high-fat diet- and rats ovariectomized were evaluated. The results shown that estradiol activates both ER1 and ER2. Meanwhile, ER2 levels increased in a dose-dependent manner [35,36]. Other studies have shown that the preventive effect of estrogen in osteoporosis is mainly via the regulation of ER1 and ER2 and affects the expressions of related proteins and genes [37,38]. Estrogen can play a neuroprotective role through estrogen receptor-mediated signaling cascade. Recent studies have shown that estrogen replacement therapy can reduce the production of $A \beta$ which impaires neurons in AD model. However, the protective effect of estrogen disappears after using ER inhibitors [39-43]. Studies have suggested that ER1 mutations found in metastatic breast cancer promote ligand-independent receptor activation and react against to estrogen-deficiency therapy in laboratory models [44]. Taken together, estrogen is exerted by binding to a receptor.

\section{Estrogen Receptors in CNS}

In the central nervous system (CNS), multiple types of estrogen receptors are widely distributed in different regions and exert different physiological functions. There are two forms of ERs in the CNS, where estrogen nuclear receptors exist as a highlight, and the distribution and functions are poles apart in several brain areas [45], including prefrontal cortex, thalamus, hypothalamus, basal forebrain, amygdala, hippocampus, raphe nucleus, locuscoeruleus, posterior cingulate $[46,47]$. On account of estrogen to be a momentous regulator of the center neurological systems that generate the symptoms associated with menopause, the location of the estrogen receptor is consistent with the associated neuroanatomy [48]. ER1 and ER2 shows a wide range of distribution in forebrain, where they regulate information processing and short-term memory, emotion and motivation, executive function and working memory, temperature, sleep, energy, balance and food intake and so on [49,50]. In the midbrain, ER2 is predominantly localized to locus coeruleus where it regulates adrenergic system functional activities such as attention, arousal and anxiety [51]. ER1 is more narrowly distributed in the hindbrain and cerebellum, and most ER1 and ER2 immunostaining is within cell nuclei [45].

\section{Estrogen disorder and AD}

In 1956, the biochemical structure of aromatic amines was studied, and the experimental sample was obtained from rat liver [52]. Androgen aromatization found in human fetuses by Naftolin and Ryan \& Petro in 1971 [53]. In the following years, it was proposed that the conversion of androgen to estrogen is aromatization in the human placenta [54]. Studies have found that aromatase is essential in the induction of male sexual behavior controlled by estradiol $[55,56]$. Finally, this enzyme has now been discovered in brain regions and other tissues or cells. In the brain of rainbow trout, aromatase genes and proteins are higher, and high expression region of aromatase is consistent with ERs in the neuroendocrine region [57]. In mammals, aromatase activity or protein expression has been detected in the hypothalamus, medial proptic area, bed nucleus of stria terminalis, prefrontal cortex, hippocampus, and cerebellum [53,58]. In other specific tissues, aromatase is mainly expressed in ovarian tissue, and it is also expressed in adipose tissue, gonads, and the like.

Recent experiments have shown that removal of ovaries can affect energy, glucose and lipid metabolism, and impaired cognitive function in rat $[19,20]$. Shin et al. reported that estrogen levels decrease in ovariectomized model rats, mimicing estrogen deficiency, and an obvious deposition of $A \beta$ in the hippocampus was found [20]. Other studies have shown that endogenous estrogen levels in naturally postmenopausal women also decreased. Therefore, natural menopause increases the risk of AD, estradiol administration in postmenopausal women may go into overtime and decrease the risk of AD [59]. Lack of estrogen can lead to an increased susceptibility to brain insulin resistance and neuroinflammation. As a result, the prevalence of $\mathrm{AD}$ increases after menopause women $[60,61]$. Estrogen is known to improve memory by promoting the degradation of $A \beta$, which may be due to it stimulating the degradation of $A \beta$ and downregulating neuroinflammation and amyloid genesis. 


\section{Estrogen Receptors and AD}

The function of estrogen receptor needs to depend on the ligand estrogen. Studies have suggested that brain estrogen has neuroprotective effects [62], and its protective effect is to affect the expression of $A \beta$ and Tau in the brain by activating estrogen receptors RE1 and ER2. The action of estrogen to degrade A $\beta$ may be mediated by binding to the receptor to regulate the activity of secretase [63].

Cav1.2 is the pore-forming subunit of CaV1 Ca2+ channel. Itis also called L-type Ca2+ channels (LTCC). Cav1.2 accounts for approximately $90 \%$ of LTCC in the brain and plays a critical role in calcium overload and cell death in AD [64]. Estrogens are neuroprotective which plays a necessary role in brain aging and $\mathrm{AD}$ $[65,66]$. It has been reported that estrogen deficiency promotes the generation of the toxic $A \beta$ and supports the role of estrogens in AD-like pathologies [67]. Evidence has suggested that physiological calcium concentration of nerve cells is necessary to maintain its normal function and increase of L-type calcium leads to neuronal damage [68]. Recent experiments have shown that brief exposure of estradiol induces a rapid increase in calcium currents, which is mediated by direct interaction of estradiol with LTCC subunit [69], and long-term estrogens can inhibit LTCC in neuronal cells $[70,71]$. A new research shows that ER1 agonist-induced Cav1.2 reduction may suggest an important role of LTCC in estrogen-mediated neuroprotection [65].

\section{ERs-Singnals Mediated and AD}

Estrogen receptors are involved in the estrogen signaling pathway, but ER-independent signaling mechanisms exist. ER-dependent pathways can initiate either in the nucleus (ER1 and ER2) or at the plasma membrane (GPR30 and ER-X). Studies have suggested that non-genomic mechanism involving interactions with the plasma membrane can also be mediated via the activation of different protein kinase cascades [28]. The G protein-coupled receptor bound to the ligand undergoes a conformational change, and the $\alpha$ subunit of the G protein is separated from the $\beta, \gamma$ subunit by exchanging the guanosine diphosphate which is originally bound to the $\mathrm{G}$ protein by guanosine triphosphate. This process makes the $\mathrm{G}$ protein active and participates in the next signaling process including the activation of the adenylyl cyclase and Src, then activation of Src activates MMP, which releases of heparin-binding epithermal growth factor (HB-EGF), and the HB-EGF can activate EGFR by which the estrogen regulate the activation of PI3K, Akt, MAPK $[63,72]$. The combined effects of these signalings and transcriptional events often promote the regeneration of neurotrophic factors. Some studies have shown that nucleus associated ER1 can also be mediated via the activation of different protein kinase cascades, MAPK/ERK, PI3K/AKT [39]. Estrogen can promote nonamyloidgenic cleavage of APP via modulation of ERK/MAPK and PI3K/Akt-dependent signals, and this effect of estrogen was mediated through activation of ER $[39,40,73,74]$. Studies have suggested that sAPP $\alpha$ stimulates the survival by signal pathway of PI3K/Akt, but A $\beta$ oligomers block signal transduction pathway, leading to the susceptibility of neurons in special parts [75]. Other studies have found that insulin can regulate the localization of presenilin 1 via the PI3K/Akt signaling pathway, thereby regulating the pathological changes of $A \beta$, which can regulate the pathological changes of $A \beta$ [76]. Studies have shown that activation of the ERK pathway can increase $\alpha$-secretase activity and sAPP $\alpha$ release and reduce amyloid production [77].

\section{Estrogen and $\mathrm{NF}-\mathrm{\kappa B}$ mediated in $\mathrm{AD}$}

In the early stages of $\mathrm{AD}$ discovery, neuropathologists have recognized that glial cells proliferate significantly in the brains of AD patients [78]. Activation of microglia and astrocytes is also extensively present in the brain of AD transgenic mice $[79,80]$. In particular, there is obvious reactive hyperplasia of glial cells around the amyloid plaque. Meanwhile, activation and proliferation of microglia in the brain, centrated around amyloid plaques, is a momentous feature for $\mathrm{AD}[81,82]$. On the other hand, there is also significant glial activation around neurons degenerated by TNFs [83]. It is further suggested that neuroinflammation is closely related to the pathological changes of $\mathrm{AD}$ characteristics. Activation of NF- $\kappa B$ promotes TNF- $\alpha$-mediated regulation of BAC1 promoter activity, which increases the production of $A \beta$ and affects the development of AD [84]. Previous studies have shown that estrogen or estrogen-like compounds administration has the potential effect to hinder the progression in mouse model of AD. Furthermore, estrogen is known to regulate the activity of proinflammatory transcription factors, such as Nuclear factorkappa-B (NF- $\kappa \mathrm{B})[85,86]$. NF- $\kappa$ B plays a critical role in the inducible transcription of various proinflammatory genes. It can selectively or directly effects regulate the expression of many genes, including cytokines (IL-1 $\beta$, IL-6), chemokines (monocyte chemotactic protein-1), and apoptotic (Fas ligand, BclXL) molecules [87-89]. NF- $\mathrm{BB}$ up-regulates the expression of many molecules that in turn modulate immune responses, inflammation, and apoptosis [90]. Furthermore, activation of NF- $\kappa$ B is involved in the treatment of $\mathrm{AD}$. NF- $\kappa \mathrm{B}$ signaling is activated and stimulates $A \beta$ production through upregulation of beta-secretase 1 expression and $\beta$-secretase activity $[91,92]$. The observation of $\mathrm{AD}$ patients supports the role of NF- $\kappa \mathrm{B}$ activation in the development of AD. Meanwhile, precursor of estrogen, $10 \beta, 17 \beta$-dihydroxyestra-1,4-dien-3-one (DHED) which is a brain-selective prodrug of $17 \beta$-estradiol, have also been studied for the treatment of AD [93]. Yan, Wu, Song, Luo and Xu [93] has confirmed that learning and memory were significantly ameliorated by prolonged treatment with DHED.

\section{Expectations}

The probability of AD development, progression, and severity of the disease exsist significant differences between men and women, and increased risk of dementia after menopause [94, 95]. Epidemiological investigation shows that the incidence of 
$\mathrm{AD}$ in postmenopausal women is about 3 times higher than in men of the same age. In the past decade of research, the role of estrogen in neuroprotection has been strengthened, and estrogen replacement therapy has many studies in AD. Early studies performed on neuronal suggested that patients with AD can use estrogen therapy for improving memory and cognitive dysfunction $[96,97]$. In addition, some studies have revealed that estrogen therapy can be effective in preventing the illness when the therapy is implemented at earlier ages [98]. It is worth noting that the transform levels of estrogen in plasma do not always reflect levels in the brain. Although estrogen has a protective effect, exogenous estrogens have not yet had a significant therapeutic effect [99-101]. Therefore, the protective effect of local estrogen is crucial in the brain, and the importance of local brain aromatase expression and activity is emphasized as the source of estradiol in the brain [102-104].

Brain estrogen and aromatase are closely related to the reduction of neuronal function. Aromatase controls the biosynthesis of estrogen, which acts to increase neuroprotection by increasing local estrogen. In the current study, the relationship between aromatase and estrogen in AD is rarely studied, and the mechanisms of action between them needs further research.

\section{References}

1. Hardy JA, Higgins GA (1992) Alzheimer's disease: the amyloid cascade hypothesis. Science 256(5054): 184-185.

2. Sindi S, Mangialasche F, Kivipelto M (2015) Advances in the prevention of Alzheimer's Disease. F1000Prime Rep 7: 50.

3. Howlett DR, Richardson JC (2009) The pathology of APP transgenic mice: a model of Alzheimer's disease or simply overexpression of APP? Histol Histopathol 24(1): 83-100.

4. Studart AN, Nitrini R (2016) Subjective cognitive decline: The first clinical manifestation of Alzheimer's disease? Dement Neuropsychol 10(3): 170-177.

5. Christidi F, Migliaccio R, Santamaria Garcia H, Santangelo G, Trojsi F (2018) Social Cognition Dysfunctions in Neurodegenerative Diseases: Neuroanatomical Correlates and Clinical Implications. Behav Neurol 2018:1849794.

6. Shupnik MA (2002) Oestrogen receptors, receptor variants and oestrogen actions in the hypothalamic-pituitary axis. J Neuroendocrinol 14(2): 85-94.

7. Schupf N, LeeJH, Pang D, Zigman WB, Tycko B, et al. (2018) Epidemiology of estrogen and dementia in women with Down syndrome. Free Radic Biol Med 114: 62-68.

8. Mielke MM, Vemuri P, Rocca WA (2014) Clinical epidemiology of Alzheimer's disease: assessing sex and gender differences. Clin Epidemiol 6: 37-48.

9. Bulun SE (2014) Aromatase and estrogen receptor alpha deficiency. Fertil Steril 101(2): 323-329.

10. Blakemore JK, Naftolin F (2016) Aromatase: Contributions to Physiology and Disease in Women and Men. Physiology (Bethesda) 31(4): 258-269.

11. Boon WC, Chow JD, Simpson ER (2010) The multiple roles of estrogens and the enzyme aromatase. Prog Brain Res 181: 209-232.
12. Roselli CE, Resko JA (1993) Aromatase activity in the rat brain: hormonal regulation and sex differences. J Steroid Biochem Mol Biol 44(4-6): 499-508.

13. Roselli CE, Resko JA (1997) Sex differences in androgen-regulated expression of cytochrome P450 aromatase in the rat brain. J Steroid Biochem Mol Biol 61(3-6): 365-374.

14. Cornil CA (2018) On the role of brain aromatase in females: why are estrogens produced locally when they are available systemically? J Comp Physiol A Neuroethol Sens Neural Behav Physiol 204(1): 31-49.

15. Azcoitia I, Sierra A, Veiga S, Honda S, Harada N, et al. (2001) Brain aromatase is neuroprotective. J Neurobiol 47(4): 318-329.

16. Chen S (1998) Aromatase and breast cancer. Front Biosci 3: d922-933.

17. Streicher C, Heyny A, Andrukhova O, Haigl B, Slavic S, et al. (2017) Estrogen Regulates Bone Turnover by Targeting RANKL Expression in Bone Lining Cells. Sci Rep 7(1): 6460.

18. Christ JP, Gunning MN, Palla G, Eijkemans MJC, Lambalk CB, et al. (2018) Estrogen deprivation and cardiovascular disease risk in primary ovarian insufficiency. Fertil Steril 109(4): 594-600.

19. Ko BS, Lee HW, Kim DS, Kang S, Ryuk JA, et al. (2014) Supplementing with Opuntia ficus-indica Mill and Dioscorea nipponica Makino extracts synergistically attenuates menopausal symptoms in estrogendeficient rats. J Ethnopharmacol 155(1): 267-276.

20. Shin BK, Kang S, Kim DS, Park S (2018) Intermittent fasting protects against the deterioration of cognitive function, energy metabolism and dyslipidemia in Alzheimer's disease-induced estrogen deficient rats. Exp Biol Med (Maywood) 243(4): 334-343.

21. Tsui KH, Huang BS, Wang PH (2016) Kisspeptin system in female reproduction: A next-generation target in the manipulation of sex hormones. J Chin Med Assoc 79(10): 519-520.

22. Casarini L, Riccetti L, De Pascali F, Gilioli L, Marino M, et al. (2017) Estrogen Modulates Specific Life and Death Signals Induced by LH and hCG in Human Primary Granulosa Cells In Vitro. Int J Mol Sci 18(5): 926.

23. Leblanc DR, Schneider M, Angele P, Vollmer G, Docheva D (2017) The effect of estrogen on tendon and ligament metabolism and function. J Steroid Biochem Mol Biol 172: 106-116.

24. Liu CH, Horng HC, Chang WH, Wang PH (2017) Granulosa cell tumor of ovary: Perspective of Taiwan. Taiwan J Obstet Gynecol 56(5): 711-712.

25. Wang N, Zhao F, Lin P, Zhang G, Tang K, et al. (2017) Knockdown of XBP1 by RNAi in Mouse Granulosa Cells Promotes Apoptosis, Inhibits Cell Cycle, and Decreases Estradiol Synthesis. Int J Mol Sci 18(6): 1152.

26. Kalita K, Szymczak S (2003) [Estrogen receptors in the brain]. Neurol Neurochir Pol 37 Suppl 3: 63-78.

27. Lewis Wambi JS, Jordan VC (2009) Estrogen regulation of apoptosis: how can one hormone stimulate and inhibit? Breast Cancer Res 11(3): 206.

28. Hayashi S, Yamaguchi Y (2008) Estrogen signaling pathway and hormonal therapy. Breast Cancer 15(4): 256-261.

29. Guivarch E, Buscato M, Guihot AL, Favre J, Vessieres E, et al. (2018) Predominant Role of Nuclear Versus Membrane Estrogen Receptor alpha in Arterial Protection: Implications for Estrogen Receptor alpha Modulation in Cardiovascular Prevention/Safety. J Am Heart Assoc 7(13): e008950.

30. Riggs BL, Khosla S, Melton LJ (1998) A unitary model for involutional osteoporosis: estrogen deficiency causes both type I and type II osteoporosis in postmenopausal women and contributes to bone loss in aging men. J Bone Miner Res 13(5): 763-773. 
31. Jeong H, Bae EK, Kim H, Eun YH, Kim IY, et al. (2017) Estrogen attenuates the spondyloarthritis manifestations of the SKG arthritis model. Arthritis Res Ther 19(1): 198.

32. Clemons M, Goss P (2001) Estrogen and the risk of breast cancer. N Engl J Med 344(4): 276-285.

33. Pike CJ (2017) Sex and the development of Alzheimer's disease. J Neurosci Res 95(1-2): 671-680.

34. Isoe Wada K, Maeda M, Yong J, Adachi Y, Harada H, et al. (1999) Positive association between an estrogen receptor gene polymorphism and Parkinson's disease with dementia. Eur J Neurol 6(4): 431-435.

35. Ting WJ, Huang CY, Jiang CH, Lin YM, Chung LC, et al. (2017) Treatment with 17beta-Estradiol Reduced Body Weight and the Risk of Cardiovascular Disease in a High-Fat Diet-Induced Animal Model of Obesity. Int J Mol Sci 18(3): 629.

36. Iorga A, Cunningham CM, Moazeni S, Ruffenach G, Umar S, et al (2017) The protective role of estrogen and estrogen receptors in cardiovascular disease and the controversial use of estrogen therapy. Biol Sex Differ 8(1): 33

37. Xiao Y, Li B, Liu J (2018) MicroRNA148a inhibition protects against ovariectomyinduced osteoporosis through PI3K/AKT signaling by estrogen receptor alpha. Mol Med Rep 17(6): 7789-7796.

38. Wu G, Xu R, Zhang P, Xiao T, Fu Y, et al. (2018) Estrogen regulates stemness and senescence of bone marrow stromal cells to prevent osteoporosis via ERbeta-SATB2 pathway. J Cell Physiol 233(5): 41944204.

39. Shi C, Zheng DD, Fang L, Wu F, Kwong WH, et al. (2012) Ginsenoside Rg1 promotes nonamyloidgenic cleavage of APP via estrogen receptor signaling to MAPK/ERK and PI3K/Akt. Biochim Biophys Acta 1820(4): 453-460.

40. Tang Y, Min Z, Xiang XJ, Liu L, Ma YL, et al. (2018) Estrogen-related receptor alpha is involved in Alzheimer's disease-like pathology. Exp Neurol 305: 89-96.

41. Tsai MC, Lin SH, Hidayah K, Lin CI (2019) Equol Pretreatment Protection of SH-SY5Y Cells against Abeta (25-35)-Induced Cytotoxicity and CellCycle Reentry via Sustaining Estrogen Receptor Alpha Expression. Nutrients 11(10): 2356.

42. Huang P, Zheng N, Zhou HB, Huang J (2019) Curcumin inhibits BACE1 expression through the interaction between ERbeta and NFkappaB signaling pathway in SH-SY5Y cells. Mol Cell Biochem.

43. Wei Y, Zhou J, Wu J, Huang J (2019) ERbeta promotes Abeta degradation via the modulation of autophagy. Cell Death Dis 10(8): 565.

44. Chandarlapaty S, Chen D, He W, Sung P, Samoila A, et al. (2016) Prevalence of ESR1 Mutations in Cell-Free DNA and Outcomes in Metastatic Breast Cancer: A Secondary Analysis of the BOLERO-2 Clinical Trial. JAMA Oncol 2(10): 1310-1315.

45. Rettberg JR, Yao J, Brinton RD (2014) Estrogen: a master regulator of bioenergetic systems in the brain and body. Front Neuroendocrinol 35(1): 8-30

46. Brinton RD (2009) Estrogen-induced plasticity from cells to circuits: predictions for cognitive function. Trends Pharmacol Sci 30(4): 212222

47. Xu Y (2017) Brain Estrogens and Feeding Behavior. Adv Exp Med Biol 1043: 337-357.

48. Brinton RD, Yao J, Yin F, Mack WJ, Cadenas E (2015) Perimenopause as a neurological transition state. Nat Rev Endocrinol 11(7): 393-405.

49. Shughrue PJ, Lane MV, Merchenthaler I (1997) Comparative distribution of estrogen receptor-alpha and -beta mRNA in the rat central nervous system. J Comp Neurol 388(4): 507-525.
50. McEwen BS, Akama KT, Spencer Segal JL, Milner TA, Waters EM (2012) Estrogen effects on the brain: actions beyond the hypothalamus via novel mechanisms. Behav Neurosci 126(1): 4-16.

51. Mitra SW, Hoskin E, Yudkovitz J, Pear L, Wilkinson HA, et al. (2003) Immunolocalization of estrogen receptor beta in the mouse brain: comparison with estrogen receptor alpha. Endocrinology 144(5): 2055-2067.

52. Booth J, Boyland E (1957) The biochemistry of aromatic amines. III Enzymic hydroxylation by rat-liver microsomes. Biochem J 66(1): 7378.

53. Naftolin F, Ryan KJ, Petro Z (1971) Aromatization of androstenedione by limbic system tissue from human foetuses. J Endocrinol 51(4): 795796.

54. Schwarzel WC, Kruggel WG, Brodie HJ (1973) Studies on the mechanism of estrogen biosynthesis. 8. The development of inhibitors of the enzyme system in human placenta. Endocrinology 92(3): 866880

55. Baum MJ, Vreeburg JT (1973) Copulation in castrated male rats following combined treatment with estradiol and dihydrotestosterone. Science 182(4109): 283-285.

56. Larsson K, Sodersten P, Beyer C (1973) Induction of male sexual behaviour by oestradiol benzoate in combination with dihydrotestosterone. J Endocrinol 57(3): 563-564.

57. Menuet A, Anglade I, Le Guevel R, Pellegrini E, Pakdel F, et al. (2003) Distribution of aromatase mRNA and protein in the brain and pituitary of female rainbow trout: Comparison with estrogen receptor alpha. J Comp Neurol 462(2): 180-193.

58. Roselli CE, Stormshak F, Resko JA (1998) Distribution and regulation of aromatase activity in the ram hypothalamus and amygdala. Brain Res 811(1-2): 105-110

59. Tang MX, Jacobs D, Stern Y, Marder K, Schofield P, et al. (1996) Effect of oestrogen during menopause on risk and age at onset of Alzheimer's disease. Lancet 348(9025): 429-432.

60. Au A, Feher A, McPhee L, Jessa A, Oh S, et al. (2016) Estrogens, inflammation and cognition. Front Neuroendocrinol 40: 87-100.

61. Yang HJ, Ko BS, Kwon DY, Lee HW, Kim MJ, et al. (2016) Asian Elm tree inner bark prevents articular cartilage deterioration in ovariectomized obese rats with monoiodoacetate-induced osteoarthritis. Menopause 23(2): 197-208

62. Correia SC, Santos RX, Cardoso S, Carvalho C, Santos MS, et al. (2010) Effects of estrogen in the brain: is it a neuroprotective agent in Alzheimer's disease? Curr Aging Sci 3(2): 113-126.

63. Lee JH, Jiang Y, Han DH, Shin SK, Choi WH, et al. (2014) Targeting estrogen receptors for the treatment of Alzheimer's disease. Mol Neurobiol 49(1): 39-49.

64. Zamponi GW, Striessnig J, Koschak A, Dolphin AC (2015) The Physiology, Pathology, and Pharmacology of Voltage-Gated Calcium Channels and Their Future Therapeutic Potential. Pharmacol Rev 67(4): 821-870.

65. Lai YJ, Zhu BL, Sun F, Luo D, Ma YL, et al. (2019) Estrogen receptor alpha promotes Cav1.2 ubiquitination and degradation in neuronal cells and in APP/PS1 mice. Aging Cell 18(4): e12961.

66. Chakrabarti M, Das A, Samantaray S, Smith JA, Banik NL, et al. (2016) Molecular mechanisms of estrogen for neuroprotection in spinal cord injury and traumatic brain injury. Rev Neurosci 27(3): 271-281.

67. Yue X, Lu M, Lancaster T, Cao P, Honda S, et al. (2005) Brain estrogen deficiency accelerates Abeta plaque formation in an Alzheimer's disease animal model. Proc Natl Acad Sci U S A 102(52): 19198-19203. 
68. Bezprozvanny I, Mattson MP (2008) Neuronal calcium mishandling and the pathogenesis of Alzheimer's disease. Trends Neurosci 31(9): 454-463.

69. Sarkar SN, Huang RQ Logan SM, Yi KD, Dillon GH, et al. (2008) Estrogens directly potentiate neuronal L-type Ca2+ channels. Proc Natl Acad Sci U S A 105(39): 15148-15153.

70. Kumar A, Foster TC (2002) 17beta-estradiol benzoate decreases the AHP amplitude in CA1 pyramidal neurons. J Neurophysiol 88(2): 621626.

71. Brewer LD, Dowling AL, Curran Rauhut MA, Landfield PW, Porter NM, et al. (2009) Estradiol reverses a calcium-related biomarker of brain aging in female rats. J Neurosci 29(19): 6058-6067.

72. Prossnitz ER, Maggiolini M (2009) Mechanisms of estrogen signaling and gene expression via GPR30. Mol Cell Endocrinol 308(1-2): 32-38.

73. Shi C, Zhu X, Wang J, Long D (2014) Estrogen receptor alpha promotes non-amyloidogenic processing of platelet amyloid precursor protein via the MAPK/ERK pathway. J Steroid Biochem Mol Biol 144: 280-285.

74. Thomas RS, Sarwar N, Phoenix F, Coombes RC, Ali S (2008) Phosphorylation at serines 104 and 106 by Erk1/2 MAPK is important for estrogen receptor-alpha activity. J Mol Endocrinol 40(4): 173-184.

75. Jimenez S, Torres M, Vizuete M, Sanchez Varo R, Sanchez Mejias E, et al. (2011) Age-dependent accumulation of soluble amyloid beta (Abeta) oligomers reverses the neuroprotective effect of soluble amyloid precursor protein-alpha (SAPP(alpha)) by modulating phosphatidylinositol 3-kinase (PI3K)/Akt-GSK-3beta pathway in Alzheimer mouse model. J Biol Chem 286(21): 18414-18425.

76. Maesako M, Uemura K, Kubota M, Ando K, Kuzuya A, et al. (2010) Insulin regulates Presenilin 1 localization via PI3K/Akt signaling. Neurosci Lett 483(3): 157-161.

77. Ma G, Chen S, Wang X, Ba M, Yang H, et al. (2005) Short-term interleukin-1(beta) increases the release of secreted APP (alpha) via MEK1/2-dependent and JNK-dependent alpha-secretase cleavage in neuroglioma U251 cells. J Neurosci Res 80(5): 683-692.

78. Mnh (2002) Neuroglia in the Aging Brain. Journal of Neuropathology \& Experimental Neurology 61(3): 294.

79. Morgan D, Jantzen P, Wilcock D, DiCarlo G, Ugen K, et al. (2003) The Association of Microglial Activation and Amyloid Reduction in APP+PS1 Transgenic Mice. Current Medicinal Chemistry - Immunology, Endocrine \& Metabolic Agents 3(1): 27-32

80. Cui YQ, Wang Q, Zhang DM, Wang JY, Xiao B, et al. (2016) Triptolide Rescues Spatial Memory Deficits and Amyloid-beta Aggregation Accompanied by Inhibition of Inflammatory Responses and MAPKs Activity in APP/PS1 Transgenic Mice. Curr Alzheimer Res 13(3): 288 296.

81. Hansen DV, Hanson JE, Sheng M (2018) Microglia in Alzheimer's disease. J Cell Biol 217(2): 459-472.

82. Sarlus H, Heneka MT (2017) Microglia in Alzheimer's disease. J Clin Invest 127(9): 3240-3249.

83. Probert L (2015) TNF and its receptors in the CNS: The essential, the desirable and the deleterious effects. Neuroscience 302: 2-22.

84. Bourne K, Ferrari D, Lange Dohna C, Roßner S, Wood T, et al. (2007) Differential regulation of BACE1 promoter activity by $\mathrm{NF} \kappa \mathrm{B}$ in neurons and glia upon exposure to $\mathrm{A} \beta$ peptides. Journal of neuroscience research 85(6): 1194-1204.

85. Frasor J, Weaver A, Pradhan M, Dai Y, Miller LD, et al. (2009) Positive cross-talk between estrogen receptor and NF-kappaB in breast cancer. Cancer Res 69(23): 8918-8925.
86. Elsarraj HS, Valdez KE, Hong Y, Grimm SL, Ricci LR, et al. (2017) NEMO, a Transcriptional Target of Estrogen and Progesterone, Is Linked to Tumor Suppressor PML in Breast Cancer. Cancer Res 77(14): 38023813.

87. Tokunaga F, Iwai K (2012) LUBAC, a novel ubiquitin ligase for linear ubiquitination, is crucial for inflammation and immune responses. Microbes Infect 14(7-8): 563-572.

88. Rashidi M, Bandala Sanchez E, Lawlor KE, Zhang Y, Neale AM, et al (2018) CD52 inhibits Toll-like receptor activation of NF-kappaB and triggers apoptosis to suppress inflammation. Cell Death Differ 25(2): 392-405.

89. Liu J, Mustafa S, Barratt D, Hutchinson M (2018) Corticosterone Preexposure Increases NF- $\kappa$ B Translocation and Sensitizes IL- $1 \beta$ Responses in BV2 Microglia-Like Cells. Frontiers in Immunology 9: 3.

90. Yun J, Yeo IJ, Hwang CJ, Choi D Y, Im H S, et al. (2018) Estrogen deficiency exacerbates $\mathrm{A} \beta$-induced memory impairment through enhancement of neuroinflammation, amyloidogenesis and NF- $k \mathrm{~B}$ activation in ovariectomized mice. Brain, Behavior, and Immunity 73: 282-293.

91. Li J, Wang H (2018) miR-15b reduces amyloid-beta accumulation in SH-SY5Y cell line through targetting NF-kappaB signaling and BACE1. Biosci Rep 38(6): BSR20180051.

92. Chen CH, Zhou W, Liu S, Deng Y, Cai F, et al. (2012) Increased NF-kappaB signalling up-regulates BACE1 expression and its therapeutic potential in Alzheimer's disease. Int J Neuropsychopharmacol 15(1): 77-90.

93. Yan W, Wu J, Song B, Luo Q Xu Y (2019) Treatment with a brainselective prodrug of $17 \beta$-estradiol improves cognitive function in Alzheimer's disease mice by regulating klf5-NF- $\kappa$ B pathway. NaunynSchmiedeberg's Archives of Pharmacology 392(7): 879-886.

94. Pike CJ (2017) Sex and the Development of Alzheimer's Disease. Journal of Neuroscience Research 95(1-2): 671-680.

95. Li RN, Cui J, Shen Y (2014) Brain sex matters: Estrogen in cognition and Alzheimer's disease. Molecular and Cellular Endocrinology 389(1-2): $13-21$.

96. Seshadri S, Zornberg G, E. Derby L, W. Myers M, Jick H, et al. (2001) Postmenopausal Estrogen Replacement Therapy and the Risk of Alzheimer Disease. Archives of neurology 58(3): 435-440.

97. Compton J, Van amelsvoort T, Murphy D (2002) HRT and its effect on normal ageing of the brain and dementia. British journal of clinical pharmacology 52(6): 647-653.

98. Henderson V (2013) Alzheimer's disease: Review of hormone therapy trials and implications for treatment and prevention after menopause. The Journal of steroid biochemistry and molecular biology 142(2014): 99-106.

99. Arevalo M, Azcoitia I, M Garcia Segura L (2014) The neuroprotective actions of oestradiol and oestrogen receptors. Nature reviews. Neuroscience 16(1): 17-29

100. Henderson VW (2014) Alzheimer's disease: Review of hormone therapy trials and implications for treatment and prevention after menopause. The Journal of Steroid Biochemistry and Molecular Biology 142: 99-106.

101. McCullough L, Blizzard K, Simpson E, Oz O, Hurn P (2003) Aromatase cytochrome $\mathrm{P} 450$ and extragonadal estrogen play a role in ischemic neuroprotection. J. Neurosci 23(25): 8701-8705.

102. Yue X, Lu M, Lancaster T, Cao P, Honda S, et al. (2006) Brain estrogen deficiency accelerates A plaque formation in an Alzheimer's disease animal model. Proceedings of the National Academy of Sciences of the United States of America 102(52): 19198-19203. 
103. Azcoitia I, Sierra A, Veiga S, M Garcia Segura L (2004) Aromatase Expression by Reactive Astroglia Is Neuroprotective. Annals of the New York Academy of Sciences 1007: 298-305.
104. Prange Kiel J, Wehrenberg U, Jarry H, Rune G (2003) Para/ Autocrine regulation of estrogen receptors in hippocampal neurons. Hippocampus 13(2): 226-234.

\section{Your next submission with Juniper Publishers} will reach you the below assets

- Quality Editorial service

- Swift Peer Review

- Reprints availability

- E-prints Service

- Manuscript Podcast for convenient understanding

- Global attainment for your research

- Manuscript accessibility in different formats

( Pdf, E-pub, Full Text, Audio)

- Unceasing customer service

Track the below URL for one-step submission https://juniperpublishers.com/online-submission.php 